\title{
The Effect of Omega-3 Supplement on Serum Lipid Profile in Patients Undergoing Hemodialysis: A Randomized Clinical Trial
}

\author{
MOSADEGH JABBARI ${ }^{1}$, TERMEH KHOSHNEVIS ${ }^{2}$, ARIA JENABI ${ }^{1}$, FATEMEH YOUSEFI $^{3}$ \\ ${ }^{1}$ Nephrology Department, Rasoul-e-Akram Hospital, Iran University of Medical Science, Tehran, Iran \\ ${ }^{2}$ Internal Medicine Department, Rasoul-e-Akram Hospital, Iran University of Medical Science, Tehran, Iran \\ ${ }^{3}$ MA, Nutrition Department, Rasoul-e-Akram Hospital, Iran University of Medical Science, Tehran, Iran
}

\begin{abstract}
Background. Some recent suggestions could show omega-3 condition deficiency following prolonged hemodialysis; however, these claims and speculations have not been well demonstrated with sufficient evidences. Hence, we attempted to assess the beneficial effects of omega-3 on lipid profile in patients with end-stage renal disease (ESRD) undergoing hemodialysis.

Methods. One hundred and seventeen ESRD patients who were on maintenance dialysis in Rasoul-e-Akram and Madaen Hospitals were enrolled in this randomized clinical trial. These patients were divided into two groups randomly using block randomization method (57 patients as the case group receiving omega-3 for 12 weeks and 60 as the control group). Blood sample was taken from all patients for measurement of lipid profile, serum hemoglobin, and C-reactive protein at baseline as well as after the completion of interventions (after 12 weeks).

Results. The average change in the value of HDL-C was significantly more in the patients who received omega-3 than in the control group ( $\mathrm{MD},-7 \mathrm{mg} / \mathrm{dL} ; 95 \% \mathrm{CI},-11$ to $0 \mathrm{p}=0.000)$. Also, the reduction in serum creatinine level was more in the omega-3 group than in the control group (MD, $0.7 \mathrm{mg} / \mathrm{dL}$; $95 \% \mathrm{CI},-0.4$ to $2.1 \mathrm{p}=0.023$ ). The change in other indices including serum triglyceride, total cholesterol, and serum hemoglobin levels was not different between the two groups. The multivariable linear regression analysis showed no difference in serum HDL level between the two groups adjusted for sex, age, and time of dialysis, while the level of serum HDL-C could be adversely predicted by duration time. Similar regression model showed a between-group difference in serum creatinine in the presence of potential confounders.

Conclusion. The change in serum HDL level following use of omega-3 supplement is influenced by time of dialysis, not by drug effect. However, consumption of omega-3 can significantly reduce serum creatinine.
\end{abstract}

Key words: omega-3, supplementation, lipidprofile, hemodialysis.

\section{INTRODUCTION}

Hyperlipidemia is an important risk factor leading high mortality and morbidity in patients with chronic kidney disease. The baseline pathogenesis of lipid disturbances in dialysis conditions is first related to involve defective lipid removal especially triglyceride release alteration from the circulation probably due to reduction in the activity of hepatic triglyceride lipase [1-3]. Another pathogenesis was shown to be parathyroid dysfunction leading increase in calcium accumulation in adipose tissue and liver [4-5]. Some human and animalbased experiments have shown that parathyroidectomy or using calcium channel blockers, the normalization of serum lipid profile in dialysis patients can be achieved [6]. Moreover, it has been shown that the retention of the inhibitors of lipoprotein lipase such as Pre-beta-HDL may lead to hypertriglyceridemia [7]. All of these mechanisms can predispose the chronic kidney disease (CKD) patients to lipid profile disturbances and consequently to cardiovascular disorders. Therefore, applying lipid lowering agents can warrant preventing development of cardiovascular disorders and related adverse events in renal failure patients. Recent evidences have emphasized the valuable role of fish oil-derived bioactive fatty acids in preventing lipid profile disorders [8-10]. Fish oil and its useful derivatives such as omega-3 have well-defined preventive effects on cardiovascular adverse consequences by inhibiting coronary atherosclerosis as well as inflammatory processes [11-12]. Thus, supplying omega-3 by rich food components or by omega-3 
supplementations can effectively prevent coronary artery disease progression or its underlying risk factors such as lipid disturbances. According to this fact that chronic kidney patients undergoing hemodialysis are considerably vulnerable to metabolic and hemodynamic changes, any change in lipid profile can result in unpleasant consequences that should be quickly prevented. Some recent suggestions could show omega-3 condition inadequacy following prolonged hemodialysis [13-14]; however, these claims and speculations have not been well demonstrated by sufficient evidences. Hence, we attempted in the present study to assess the beneficial effects of omega-3 on lipid profile in patients with endstage renal disease (ESRD) undergoing hemodialysis.

\section{MATERIALS AND METHODS}

One hundred and seventeen ESRD patients who were on maintenance dialysis in Rasoul-eAkram and Madaen Hospitals were enrolled in this randomized clinical trial. These patients were divided into two groups randomly using block randomization method (57 patients as the case group receiving omega- 3 and 60 patients as the control group). The exclusion criteria were consuming on other antilipid medications, a recent history of active infectious or inflammatory disease, abnormalities documented by liver function tests. All participants gave informed consent after the nature and intent of the study was fully explained to them. The research protocol was approved by the Ethics Committee of Iran University of Medical Sciences. In our experiment, the patients in the omega-3 group received one pill of omega- $3(1000 \mathrm{mg})$ with each meal for 12 weeks. Participants in the placebo group were assigned to use oral pills of placebo for the same time. Baseline characteristics, including demographics, anthropometric parameters, disease and dialysis duration and oral medications were collected by interview. Blood sample was taken from all patients for measurement of lipid profile, serum hemoglobin, serum creatinine and C-reactive protein at baseline as well as after the completion of interventions (after 12 weeks). Serum total cholesterol and triglyceride were measured by applying the enzymatic method and HDL and LDL particles by means of the homogeneous assay method using an automated analyzer. Serum hemoglobin was measured by cyanide methemoglobin method.
For statistical analysis, results were presented as mean \pm standard deviation (SD) for parametric quantitative variables and median $\left(1^{\text {st }}, 3^{\text {rd }}\right.$ quartiles $)$ for nonparametric variables and were summarized by absolute frequencies and percentages for categorical variables. Normality of data was analyzed using the Kolmogorov-Smirnoff test. Categorical variables were compared using chi-square test or Fisher's exact test, when more than $20 \%$ of cells with expected count of less than 5 were observed. Quantitative variables were also compared with $t$ test or Mann- Whitney U test. The change in study parameters after completing study interventions compared to baseline was assessed using the Paired $\mathrm{t}$ test or non-parametric Wilcoxon test. The multivariate linear regression model was also used to compare the change in parameters between the two study groups with the presence of baseline variables. For the statistical analysis, the statistical software SPSS version 16.0 for windows (SPSS Inc., Chicago, IL) was used. P values of 0.05 or less were considered statistically significant.

\section{RESULTS}

The details of baseline characteristics were primarily compared between the omega-3 group and control group. As shown in Table 1, the two groups were similar in terms of mean age, mean body mass index and prevalence of diabetes mellitus, whereas male to female ratio, prevalence of hypertension, and prevalence of polycystic kidney disease (PCKD) were significantly higher in those patients receiving omega-3 than in the control group. Comparing lipid profiles after interventions compared to the baseline (Table 2), the average increase in the value of HDL-C was significantly higher in the patients who received omega-3 than in the control group (MD, $-7 \mathrm{mg} / \mathrm{dL} ; 95 \% \mathrm{CI},-11$ to $0 \mathrm{p}=0.000)$. Also, the reduction in serum creatinine level was more important in the omega-3 group than in the control group (MD, $0.7 \mathrm{mg} / \mathrm{dL}$; $95 \% \mathrm{CI},-0.4$ to $2.1 \mathrm{p}=0.023$ ). The change in other indices including serum triglyceride, total cholesterol, and serum hemoglobin levels was not different between the two groups. We also showed that there was no difference in the mean duration of dialysis between omega- 3 and control groups $24(12,48)$ years versus $12(7.25,36), \mathrm{p}=0.083)$. The multivariable linear regression analysis (Table 3 ) showed no difference in serum HDL level between the two 
groups adjusted for sex, age, and time of dialysis $(p=0.138)$, while the level of serum HDL-C could be adversely predicted by duration time. Similar regression model (Table 4) showed a betweengroup difference in serum creatinine in the presence of potential confounders.

Table 1

Baseline characteristics between the omega-3 group and control group

\begin{tabular}{lccc}
\hline \multicolumn{1}{c}{ Characteristics } & Omega-3 group & Control group & P-value \\
\hline Male gender & $42(73.7 \%)$ & $33(55.0 \%)$ & 0.035 \\
\hline Age, years & $64.58 \pm 12.61$ & $61.05 \pm 17.42$ & 0.211 \\
\hline BMI, $\mathrm{kg} / \mathrm{m}^{2}$ & $20.37 \pm 2.82$ & $20.65 \pm 2.86$ & 0.593 \\
\hline Hypertension & $15(26.3 \%)$ & $30(50.0 \%)$ & 0.008 \\
\hline Diabetes mellitus & $33(57.9 \%)$ & $33(55.0 \%)$ & 0.752 \\
\hline PCKD & $9(15.8 \%)$ & $0(0.0 \%)$ & 0.001 \\
\hline
\end{tabular}

Table 2

The change in study parameters after intervention in the omega-3 group and control group

\begin{tabular}{lccc}
\hline \multicolumn{1}{c}{ Characteristics } & Omega-3 group & Control group & P-value \\
\hline Triglyceride & $-3(-30,17)$ & $-3.5(-13.2,4.7)$ & 0.496 \\
\hline Total cholesterol & $-3(-21,10)$ & $-5(-15.5,6.5)$ & 0.776 \\
\hline LDL-C & $4(-2,10)$ & $-2(-8,13)$ & 0.580 \\
\hline HDL-C & $-7(-11,0)$ & $3(-9.5,7.5)$ & 0.000 \\
\hline Serum creatinine & $0.7(-0.4,2.1)$ & $0.4(-1,1.15)$ & 0.023 \\
\hline Serum hemoglobin & $-0.4(-2.3,-0.1)$ & $-0.95(-1.7,0.25)$ & 0.733 \\
\hline
\end{tabular}

Table 3

Multivariate linear regression analysis to assess group difference in serum HDL level

\begin{tabular}{|c|c|c|c|c|c|}
\hline \multirow{2}{*}{ Variable } & \multicolumn{2}{|c|}{ Unstandardized Coefficients } & \multirow{2}{*}{$\begin{array}{c}\begin{array}{c}\text { Standardized } \\
\text { Coefficients }\end{array} \\
\text { Beta }\end{array}$} & \multirow{2}{*}{$\mathbf{t}$} & \multirow{2}{*}{ Sig. } \\
\hline & B & Std. Error & & & \\
\hline (Constant) & 1.459 & 7.487 & & .195 & .846 \\
\hline Group & 4.135 & 2.767 & .137 & 1.495 & .138 \\
\hline Sex & 1.802 & 2.951 & .057 & .611 & .543 \\
\hline Age & -.148 & .093 & -.149 & -1.585 & .116 \\
\hline Time* & -.146 & .054 & -.248 & -2.734 & .007 \\
\hline
\end{tabular}

${ }^{*}$ duration of dialysis

Table 4

Multivariate linear regression analysis to assess group difference in serum creatinine level

\begin{tabular}{lccccc}
\hline \multirow{2}{*}{ Variable } & \multicolumn{2}{c}{ Unstandardized Coefficients } & $\begin{array}{c}\text { Standardized } \\
\text { Coefficients }\end{array}$ & \multirow{2}{*}{ t } & \multirow{2}{*}{ Sig. } \\
\cline { 2 - 5 } & $\mathbf{B}$ & Std. Error & Beta & & \\
\hline (Constant) & 2.939 & .790 & & 3.719 & .000 \\
\hline Group & -.580 & .292 & -.186 & -1.984 & .050 \\
\hline Sex & -.513 & .312 & -.158 & -1.647 & .102 \\
\hline Age & -.015 & .010 & -.146 & -1.524 & .130 \\
\hline Time & .000 & .006 & -.016 & -.174 & .862
\end{tabular}

\section{DISCUSSION}

The information that this study is the second largest study with omega-3 in hemodialysis patients. In parallel with the previous findings on beneficial effects of omega-3 supplying on lipid lowering in people who were predisposed to cardiovascular disorders especially patients with ESRD, our study aimed to assess the effects of consuming omega-3 on serum lipid profiles in patients undergoing hemodialysis. In this context, our study had two important findings. First, we could show that although serum HDL was more significantly changed in omega-3 group than in the control group, considering time of dialysis as an important baseline parameter showed that the level of serum HDL was more affected by this factor than by drug intervention. In other words, more change in serum HDL level was 
in line with prolonged dialysis in ESRD patients. As another important result, the level of serum creatinine was directly affected by using omega- 3 supplement adjusted for other baseline indices factors such as time of dialysis. Reviewing the previous studies could also find similar results regarding beneficial effects of omega-3 on lipid profile. In a recent study by Omrani et al. [15], 10 weeks treatment with omega-3 leads to more lower total cholesterol but no other lipid particles such as serum HDL, LDL, or triglyceride levels. In another study by Taziki et al. and similar to ours [16], consumption of omega-3 supplement for 12 weeks led to reduction in serum HDL level without significant difference in other lipid profiles. Hassan et al. [17] also showed that the use of omega-3 for 8 weeks resulted in significantly reduced serum triglycerides, but without observable change in other lipid components such as cholesterol, LDL, or HDL. In fact, the consumption of omega-3 supplement with the different dosages for different treatment time might be accompanied with different effects on lipid profiles. Some studies could describe the mechanisms of the impact of omega-3 on lipid metabolism. It has been well shown that omega-3 fatty acids can decrease the synthesis and secretion of VLDL particles, and also increase TG removal from VLDL and chylomicron particles through the upregulation of enzymes, such as lipoprotein lipase [18]. As previously pointed, it seems that the effects of omega-3 on lipid profiles are completely dose dependent. In a review by Harris et al. [19], $4 \mathrm{~g} /$ day of omega-3 fatty acids from fish oil decreased serum triglyceride concentrations to $25-30 \%$. There were accompanying increases in low density lipoprotein (LDL) cholesterol of $5-10 \%$, in high density lipoprotein (HDL) cholesterol of $1-3 \%$ and a dose-response relationship between omega-3 fatty acid intake and triglyceride lowering. In total, the effects of omega-3 on lipid profiles such as HDL may be intensified by prolonged hemodialysis. In fact, as indicated in our study, the main mechanism for increase the level of HDL following omega- 3 use may be affected by the time of dialysis, so prolonged dialysis can cause lower change in HDL level. As Lapuz et al. [20] showed an inverse correlation of total cholesterol and HDL levels with months on dialysis. Thus, the change in HDL is mainly associated with time of dialysis, but not with the mechanical effects of omega-3 on lipids.

As another important result and in contrary to the effect of omega-3 on lipids, this supplement could effectively reduce serum creatinine, which is a remarkable finding. In a meta-analysis by Chi et al. [21] it was shown that Omega-3 supplementation could significantly decrease the levels of TG (MD, $-34.8 \mathrm{mg} / \mathrm{dL} ; 95 \% \mathrm{CI},-62.32$ to -7.28$)$ and LDL (MD, $-7.15 \mathrm{mg} / \mathrm{dL} ; 95 \% \mathrm{CI},-10.11$ to -4.2 ).

It was previously pointed in some similar studies. In an animal study by Ashtiyani et al. [22], the decrease in glomerular filtration rate induced by reperfusion was relatively improved by omega- 3 administration, which resulted in the decrease in plasma urea and creatinine concentrations. The use of omega-3 might be also preventive for renal dysfunction. As indicated by Holm et al. [23], plasma creatinine increased and glomerular filtration rate decreased in the placebo group, while no changes were observed in the omega-3 group, for explaining the preventive effect of this drug on renal dysfunction. Therefore, the use of omega-3 supplement can effectively reduce serum creatinine that is very vital for CKD patients.

\section{CONCLUSIONS}

Using omega-3 supplement leads to increase in serum HDL concentration, however this significant change may be indirectly affected by time on dialysis, not directly by the effects of omega-3 on lipid metabolism. In this study, omega-3 significantly reduced serum creatinine, which could be an important therapeutic effect of this medication in ESRD patients undergoing dialysis.

Conflict of interest. There is no conflict of interest.

Acknowledgment. Authors wish to thank Rasoul-e-Akram Hospital, Clinical Research Development Center for technically supported implementation of the project.

Introducere. Studii recente au arătat faptul că acizii graşi omega-3 ar avea beneficii la pacienții cu hemodializă prelungită. Totuşi sunt necesare studii suplimentare care să aducă un nivel al evidenței mai mare. Scopul studiului a fost de a evalua efectele benefice ale acizilor graşi omega-3 asupra profilului lipidic la pacienții cu boală renală cronică în stadiul final (ESRD) ce sunt supuşi hemodializei. 
Materiale şi metode. 117 pacienți ESRD din spitalele Rasoul e-Akramsi Madaen au fost incluşi în acest studiu clinic randomizat. Aceştia au fost împărțiți in două grupuri după ce a avut loc randomizarea în bloc (57 de pacienți au primit omega-3 pentru 12 săptămâni şi 60 au constituit grupul martor). Au fost prelevate probe sanguine pentru analiza profilului lipidic, hemoglobinei, nivelurile proteinei $C$ reactive atât la momentul înrolării, cât şi ulterior după finalizarea celor 12 luni.

Rezultate. Valorile HDL-colesterolului au fost modificate mai mult în grupul cu omega-3 comparativ cu grupul martor (MD, -7 mg/dL; 95\% CI, -11 la $0 p=0.000)$. În plus, reducerea creatininei serice a fost mai importantă în grupul ce a primit tratament cu omega-3 comparativ cu grupul martor ( $M D, 0.7 \mathrm{mg} / \mathrm{dL} ; 95 \% \mathrm{CI},-0.4$ la $2.1 p=0.023)$. Nu au fost diferențe semnificative intre modificările survenite la nivelul valorilor trigliceridelor serice, ale hemoglobinei sau ale colesterolului total. Analiza de regresie multivariată a arătat că nu este nicio diferență semnificativă statistic între nivelurile $H D L$ colesterolului după ce s-a făcut ajustarea după sex, vârstă şi durata dializei. Un model similar de regresie a arătat faptul că există o diferență între valorile serice ale creatininei în prezența anumitor factori de confuzie.

Concluzii. Modificările datorate HDL-colesterolului apar mai ales datorită duratei dializei şi nu a suplimentării cu omega-3 însă terapia cu omega-3 ar putea scădea semnificativ nivelurile creatininei serice.

Correspondence to: TermehKhoshnevis, MD, Nephrology Department, Rasoul-e-Akram Hospital, Iran University of Medical Science, Tehran, Iran

Tel: +989126199295

Email: khoshnevis_med80@yahoo.com.

\section{REFERENCES}

1. SENTÍM, ROMERO R, PEDRO-BOTET J, PELEGRÍA, NOGUÉS X, RUBIÉS-PRAT J. Lipoprotein abnormalities in hyperlipidemic and normolipidemic men on hemodialysis with chronic renal failure. Kidney Int. 1992; 41:1394.

2. ATTMAN PO, SAMUELSSON O, ALAUPOVIC P. Lipoprotein metabolism and renal failure. Am J Kidney Dis. 1993; $21: 573$.

3. ARNADOTTIR M, THYSELL H, DALLONGEVILLE J, FRUCHART JC, NILSSON-EHLE P. Evidence that reduced lipoprotein lipase activity is not a primary pathogenetic factor for hypertriglyceridemia in renal failure. Kidney Int. 1995; 48:779.

4. LACOUR B, ROULLET JB, LIAGRE AM, JORGETTI V, BEYNE P, DUBOST C, DRÜEKE T. Serum lipoprotein disturbances in primary and secondary hyperparathyroidism and effects of parathyroidectomy. Am J Kidney Dis. 1986; 8:422.

5. LIANG K, OVEISI F, VAZIRI ND. Role of secondary hyperparathyroidism in the genesis of hypertriglyceridemia and VLDL receptor deficiency in chronic renal failure. Kidney Int. 1998; 53:626.

6. AKMAL M, PERKINS S, KASIM SE, OH HY, SMOGORZEWSKI M, MASSRY SG. Verapamil prevents chronic renal failure-induced abnormalities in lipid metabolism. Am J Kidney Dis. 1993; 22:158.

7. CHEUNG AK, PARKER CJ, REN K, IVERIUS PH. Increased lipase inhibition in uremia: identification of pre-beta-HDL as a major inhibitor in normal and uremic plasma. Kidney Int. 1996; 49:1360.

8. KRIS-ETHERTON PM, HARRIS WS, APPEL LJ, et al. American Heart Association, Nutrition Committee. Fish consumption, fish oil, omega-3 fatty acids, and cardiovascular disease. Circulation. 2002; 106:2747-2757.

9. SERHAN CN, HONG S, GRONERT K, et al. Resolvins: a family of bioactive products of omega-3 fatty acid transformation circuits initiated by aspirin treatment that counter proinflammation signals. J Exp Med.2002;196: 1025-1037.

10. HARRIS WS. N-3 fatty acids and serum lipoproteins: human studies. Am J Clin. Nutr. 1997; 65:1645S-1654S.

11. ERITSLAND J, ARNESEN H, GRONSETH K, et al. Effect of dietary supplementation with $n-3$ fatty acids on coronary artery bypass graft patency. Am J Cardiol. 1996; 77:31-36.

12. THIES F, GARRY JM, YAQOOB P, et al. Association of $n-3$ polyunsaturated fatty acids with stability of atherosclerotic plaques: a randomized controlled trial. Lancet. 2003; 361:477-485.

13. FRIEDMAN AN, MOE SM, PERKINS SM, et al. Fish consumption and omega-3 fatty acid status and determinants in longterm hemodialysis. J Am Kidney Dis 2006:1064-1071.

14. FRIEDMAN AN, SIDDIQUI R, WATKINS BA. Acute rise of omega-3 polyunsaturated fatty acids during hemodialysis treatment. J Ren Nutr 2008; 18(3):301-3. 
15. OMRANI HR, PASDAR Y, RAISI D, NAJAFI F, ESFANDIARI A. The effect of omega-3 on serum lipid profile in hemodialysis patients. J Renal Inj Prev. 2015; 4:68-72.

16. TAZIKI O, LESSAN-PEZESHKI M, AKHA O, VASHEGHANI F. The effect of low dose omega-3 on plasma lipids in hemodialysis patients. Saudi J Kidney Dis Transpl. 2007; 18(4):571-6.

17. HASSAN KS, HASSAN SK, HIJAZI EG, KHAZIM KO. Effects of omega-3 on lipid profile and inflammation markers in peritoneal dialysis patients. Ren Fail. 2010; 32:1031-5.

18. BAYS HE, TIGHE AP, SADOVSKY R, DAVIDSON MH. Prescription omega-3 fatty acids and their lipid effects: physiologic mechanisms of action and clinical implications. Expert Rev Cardiovasc. Ther. 2008; 6:391-409.

19. HARRIS WS. N-3 Fatty acids and serum lipoproteins: human studies. Am J Clin. Nutr 1997; 65:S1645-54.

20. LAPUZ M, AVRAM MM, LUSTIG A, GOLDWASSER P, ANTIGNANI A, FEIN PA, et al. Fall of cholesterol with time on dialysis: impact on atherogenicity. ASAIO Trans. 1989; 35:258-60.

21. CHI H, LIN X, HUANG H, ZHENG X, LI T, ZOU Y. Omega-3 fatty acid supplementation on lipid profiles in dialysis patients: meta-analysis. Arch Med Res. 2014; 45:469-77.

22. ASHTIYANI SC, NAJAFI H, KABIRINIA K, VAHEDI E, JAMEBOZORKYL. Oral omega-3 fatty acid for reduction of kidney dysfunction induced by reperfusion injury in rats. Iran J Kidney Dis. 2012; 6:275-83.

23. HOLM T, ANDREASSEN AK, AUKRUST P, ANDERSEN K, GEIRAN OR, KJEKSHUS J, et al. Omega-3 fatty acids improve blood pressure control and preserve renal function in hypertensive heart transplant recipients. Eur Heart J. 2001; 22:428-36.

Received March 9, 2016 